\title{
Push And Pull Factors Of Internal Migration In Balochistan Province: A Case Study
}

\author{
Nisar Ahmed \\ \& \\ Sumera Ishrat \\ Department of Social Work \\ University of Karachi
}

\begin{abstract}
The purpose of this study is to explore various push and pull factors of internal migration in Balochistan, to get an insight to the social life of migrants and investigate the psychological issues along with their health status. The present study was Exploratory in nature. The Universe was selected as District Hubchowki, District Gwadar and District Turbat, Balochistan. The Population comprised on the heads of families (Male Member). The data was collected by Snowball Sampling Techniques. Research Instruments like Questionnaire and Observation used for data collection. The data analysis and Hypotheses Testing was conducted through statistical methods. The recommendations of the study were comprised of the increasing rate of rural to urban migration over the time in Pakistan reflect the urban bias government polices along with lack of planning and implementation of rural development programs and schemes in the country. It will provide meaningful future urban planning in the country as migration has vast socio-economic impact upon habitants of the country. All these factors have significant relationship with the internal migration.
\end{abstract}

Keywords: Push and Pull Factors, Internal Migration Patterns, Resettlement, Socio-Economic Impacts and Migrants.

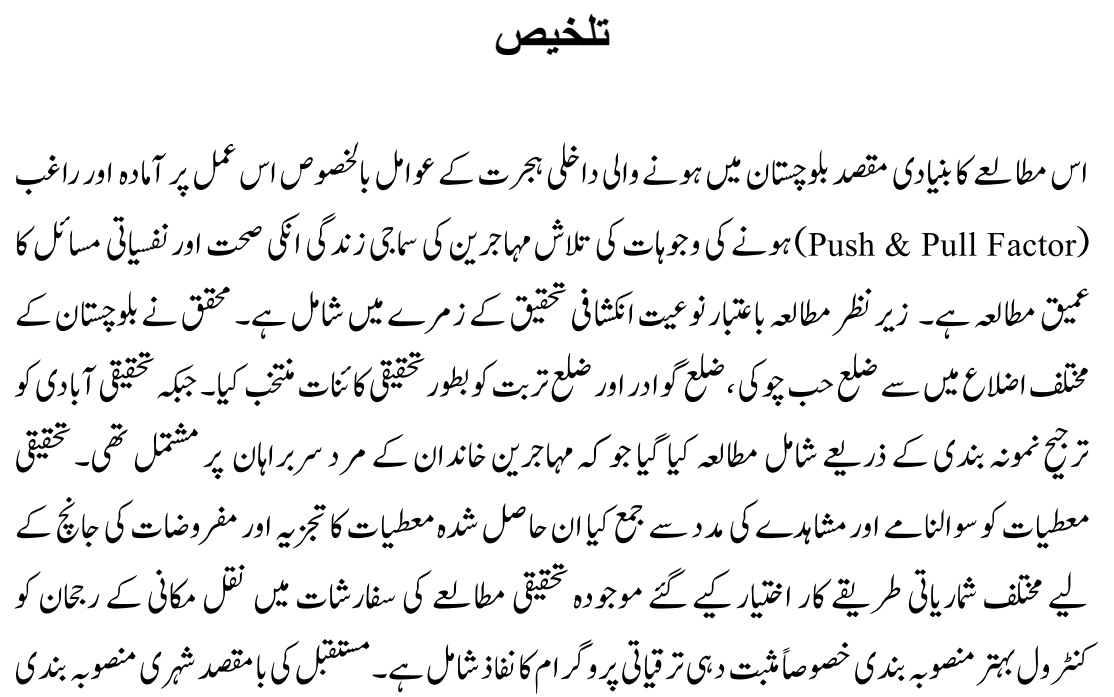




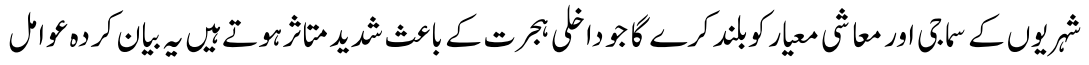

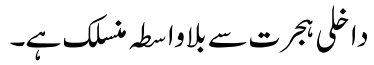

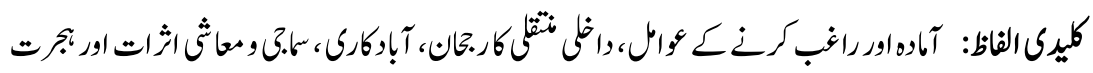

$$
\begin{aligned}
& \text { كرن }
\end{aligned}
$$

\section{Introduction}

The push and pull factors in internal migration, a key factor of changes in population distribution and a major driving force in the process of urbanization. However, the level and patterns of internal migration remain poorly documented in many countries, particularly in the developing world, because the data required estimating internal migration from population censuses are not collected, or it is not published with sufficient detail. One major challenge of modern and future urbanization derives from the fact that practically all urban population growth will take place in developing countries, and that a large proportion of the future growth of the urban population will live in conditions of poverty.

Migration is the movement process from one place to another and generally connected with change of permanent place of habitation. And the reasons of internal migration are interregional and intraregional differences at function level and basically lack of job opportunities causing low standard of living conditions among various socio-economic groups at micro level. There are following components of population change such as: mortality, fertility and migration, and also there are two types of migration namely internal migration and international migration. However, internal migration is the movement of people from one place to other place within the country. While, international migration is the movement of people from one country to another in order to better income and also increasing their living standard.

Various scholars study the migration for different purposes. Sociologists have emphasized social and cultural consequences of migration. While geographers have laid stress on the time and distance significance of migration, economists emphasize on the economic aspect of migration. Experts have discovered some significant push and pull factors of migration which consist of:

(i) Various social, political and caste system prevalent in the country. (ii) Decreased employment opportunities in rural areas owing to heavy mechanization. (iii) The reduction of per capita share of labour in agriculture field unavailability of limited agriculture land in the rural areas. (iv) Industrial development in the country, growing influence of timber mafia and development in modern technology. (v) Improved economic condition, increase wages, better 
basic facilities like cleanliness, transportations and advance communication skills in urban areas. (vi) Good educational opportunities, well standard of life, liberty in every sphere of life, peaceful environment in the modern societies. (vii) Modern of the hart facilities of health and recreational activities for the people. In the medieval era, the first wave of 'permanent' settlement out of Balochistan occurred in the 14th century (Solimano, 2002).

According to the writer, globally there are at least 740 million internal migrants; compare this with only 232 million international migrants. Internal migrants are facing many challenges including social isolation, discrimination, forced evictions and poor working conditions and have the same needs and human rights as international migrants. However, the internal migration is occasionally studied or considered at the international Program and policy level (United Nation, 2013).

During the period 2011 to 2050, the world's urban population is projected to increase from 3.6 billion to 6.3 billion. Most of this increase will be in the cities and towns of developing and less developed countries. Consequently, it is expected that half of Asia's and Africa's population will be living in urban areas by 2020 and 2035 separately. It is estimated that the world's urban population will increase by 1.4 billion over the period 2011 and 2030(Montgomery, 2008).

Migrating from rural to urban areas has been of great significance as it has change the rapid growth of cities coupled with reclassification of rural areas into urban areas, it continues to be important chain of city growth. Although, there is rapid increase in birth rate as compare to death rate which contributes to urban growth and reclassify the majority of developing countries (United Nation, 2009).

In-migrants also joined in agriculture and elementary occupations along with crafts work. However, comparison of income profile revealed that in-migrants were slightly better off than non-migrants. Further, rural households received almost four times higher settlements as compared to their urban complements. The effect of internal remittances, however, was noted to be knowingly marginal as compared to the remittances received by international migration. Consequently, the socioeconomic status of the rural migrants remained unprivileged with higher percentage of stunted children as compared to non-migrants' children (Arif, G. M, 2005).

According to the point of view of writer mentioned that the other macro-economic variables of interest include health and education, marriage, groundwork, informational and migrant networks at destination; and poverty, population density and landlessness at place of origin. Consequently, the households and families may have strategies to diversify their livelihoods, such as keeping some members in the village, while other members follow education and yet others work in an urban area and send remittances home (Friesen, W., 1986).

In Pakistan historically, the distribution amongst provinces has exclusively been on the basis of population. The 7th NFC award in 2009 was a breakthrough for fiscal 
reorganization in the country as the provincial shares have expanded to 56 percent from 37 percent they received under the last award and for the first time population is not the sole criterion for resource sharing between the provinces. However, the 18th amendment has brought many federal subjects into the provincial domain. Also, for this reason it becomes relevant to study the incentives that migrants in the country respond to when selecting the destination district. Discovering what these encouragements have been historically can give us clues about the danger, or otherwise, of the phenomenon of process unfolding in Pakistan (Tiebout, 1956).

The Government of Pakistan fully recognizes the severe socio-economic implications of high fertility and rapid population growth and the focus is now on the implementation of an effective population policy operating within the framework of well-defined development goals. The population policy 2002 is plan to bring down population growth rate from its current level to 1.9 percent by the year 2004 and 1.3 percent by 2020 . However, fertility is planned to be reduced to 4 births per woman by 2004 and reach a replacement level by the year 2020 (Ministry of Population Welfare, 2002).

The relationship within the family tend to give rise to migration as the family member relays information best on their experience as they are bound to family obligation. Before hundreds of years of seasonal migration, the first wave of 'permanent' settlement out of Balochistan took place in the 14th century. The north-west of Balochistan was too much cold and was not inhabitable in the winter. The people had to go down to the plains in the south. This process continued for several hundred years. The second wave of migration took place due to two serial droughts, first in 1669 and then an extremely severe one after one hundred years. Its effects felt from coastal area of Balochistan to Chabahar as a result thousand people died. They had no option but to migrate we can see today that Baloch are settled in various areas such as, Gadap, Malir, Kahore, Mauripur, Lyari and Mawanch etc. Although writer mentioned that some slaves refused to abandon their masters and preferred to die along with them. In this regard the wave of migration also brought Baloch from Makran came to Sindh. However, these people are the Baloch of African ancestry, as they were sold in Balochistan as slaves by the Arab traders (Baloch, Akthar, 2014).

According to the Chief Minister's Policy Reform unit Gov't of Baluchistan, the development strategy approximates the 'Big Push' and 'Unbalanced' growth theories. The 'Big Push' is aimed at creating a large stock of economic assets in selected sectors and areas and the resultant 'inter-sectorial imbalance' is expected to trigger a 'pull effect' for the rest of the economy. Admittedly, these theories were enunciated in the 1950s, but that is where Balochistan still stands (Akbar, Siraj, Malik, 2014).

However, internal migration has effects on the destination of the people and the place left behind. People move from one place for searching job opportunities, 
new rental property or obtained home. Education is also one of the reasons that embolden people to recourse to internal migration. Besides, it is one of the instincts of human nature to change places of living after a great length of time. Environment also plays in active role during internal migration.

There are certain reasons of migration from rural to urban area in Balochistan, one of the major reason are push \& pull factors as well as the influx of Baloch insurgents for better safety and secure environment, benefits. Consequently, shortage of water and lack of basic health, education facilities, cause the raising tools of migration from rural to urban areas for the purpose of availing basic needs and get red from unabated insurgents antigovernment activities. Lakeview's inhabitant rapidly migrated from rural to urban areas to pass a better life as well.

\section{Causes / Factors of Migration}

The push factors are elements that force an individual, due to multiple reasons, to leave their hometown and settle on other place. The common push factors are the recognition of unemployment and low productivity and poor economic conditions, lack of opportunities for development in underdevelopment country. However, the non-availability of other sources of income in village area is also a major factor of migration. The pull factors are factors which draw the attraction of migrants from rural to urban area. While, to avail the better opportunities, higher incomes, better working environments and other basic facilities as well as better conveniences are pull factors of an urban area.

There are following various factors of migration such as: The important factors which motivate people to move can be classified into five categories. They are economic factors, demographic factors, socio-cultural factors, political factors and miscellaneous factors.

There are a large number of reasons for people to move from one place to another. These reasons can be political, social, economic or environmental. Together they form what are known as push and pull factors, and migration results from one or a combination of these. Push factors may include unemployment, lack of safety and security, crop failure, drought or floods etc., and these would be situations that people find themselves in in source areas. The pull factors may include potential for employment, a better safety environment, better service provision, fertile land, and a good food supply, less likelihood of natural disasters, more affluence and greater political stability.

\section{Review of Literature}

The historical literature on migration is fixed in models of development that assume to the all countries, at some stage of their development, have experienced 
the movement of their labour force from the agricultural sector as well as the non-agriculture sector. However, this intersect oral allocation of labour has implied geographical movement of workers from rural (agricultural) areas to urban (industrialized) areas.

In migration research frequently known theoretical concepts are contained in economic models of migration and also called push \& pull factor for the clarification of the causes of migration. Mostly the push and pull factors draw a number of negative factor in the country of origin that is the reason of people to leave away and also arrangement with a number of positive factor that attract migrants with in the country. However, push factors listed such origins as economic, social and political needs in the under developing countries while, the pull factor include the reasonable benefits in the developed countries. In order to the combination of push and pull factors would then regulate the size and direction of movements (Portes \& Böröcz, 1989).

This structure of population is also particular to the appearances of the sending and receiving places in term of push and pull factor resulting in; from rural to urban, from urban to urban, from rural to rural, and from rural to urban migration. The migration is mainly of two types with respect to boarder of the country: national and international migration (internal and external migration). Many factors are responsible for these types of migration.

A great deal of academic and policy literature has addressed the factors that shape human mobility decisions and subsequent migration trajectories. The bases for the push-pull migration that is sine qua non is provided in Raven stein's seven 'laws' of migration $(1885,1889)$ that gain traction in later decades. In the context of theoretical contributions of Lee (1966), it identified four factors that influences population and established that push-pull as one of the most important factor in migration study.

Considering its influence on subsequent literature, the push-pull scheme developed by expert must be thoroughly studied. Theory of migration recommends that there are four kinds of factors that cause mobility: 1) Factors associated with the origin area, 2) Factors associated with the destination area, 3) Intervening obstacles, and 4) Personal factors. In both areas of origin and destination, there may be factors that act to hold, retain, or attract people (pull factors) or those that repel people (push factors). Such factors change from individual to individual, whose subsequent mobility decisions will be arranged by a various experience and understanding of factors. Expert stated that simple perks and benefits do not motivate migration, given the nature of is dormancy, rather than its human instinct that pushes him towards migration. The decision to migrate depends upon the nature of the obstacles that he may face and the nature of the destination that embolden him for migration (Lee, E. S, 1966). 
The research in a systematic way on the topic of internal migration and its determinants mainly started in nineteenth century. Now in present much research and literature is dedicated on the different aspects and topics of internal migration. It clarifies the causes and reasons of internal migration; and also its vast impacts up socio-economic, geo-political and demographic structure of families' push \& pull factors and societies in regions of the world. In fact, the aim of internal migration is to elaborate the previous trends and predict possible migration module in future. It is a subject of compound occurrence, there for it consists of different areas of demography, sociology, economics and geography as well as others.

Though, a theoretical framework of migration established that migration is caused by different factors including age, structures, market, resource mobility and policies of state (Sjaastad, L. A, 1962).

There are certain elements of neoclassical theory such as: salary differential as a main motivation for migration which powerfully supported by realistic proof, the expectations and simplicity of economic rational actor flexibility of frameworks have been deeply condemned by theorists. Evaluations have focuses around the limited studies and theories on economic factors, their focus on the individual as a decision maker as well as expectations on perfectly running markets and assumptions about the comprehensive knowledge and wisdom of actors, and also the treatment of migrants as a standardized group. While, purely economic theories fail to explain the complications of migration due to their challenging expectations, they do definitely provide benefits such as the ability to size and forecast the individual behaviours (Boswell, 2008).

It is an established fact that cities developed very fast, because there are modern of the hart facilities available. The extent of urbanization can be realized from the fact that population of twenty extra-large cities has crossed over ten million during the year 2011. All these cities are located in developing countries suppose three of them are in the developed countries. The main reasons for the growth of urban areas in these countries might be due to high population growth rate and increasing internal migration from rural to urban areas. The bulge of internal migration in Pakistan has rapidly increased almost 6 times during the period from 1951 to 1998. It is almost the double population as compared to the population of the country in same time period (Karim, M. \& Abu Nasar, 2003).

Obviously, once migration connections have been recognized due to the presence of relatives, friends, and others within the same community of origin may formulate a strong encouragement to choose a specific destination. Other factor would be a common language, information about the countries images through social media for the purpose of finding job opportunity, awareness about the function admission and additional strategies. However, strong push and pull factors connected to labour market and economic differences as well as political and environment conditions, favorable the remarkable advancement to moving and communication systems may also encourage migrants to travel from a new destinations (Ghosh, 1992). 


\section{Objectives}

- To explore various push and pull factors of internal migration.

- To know the education opportunities, psychological status and health conditions of internal migrants.

- To know the views and experience of the migrants regarding migration process.

\section{Hypotheses}

1) There will be significant relationship between educational level and migration caused due to gender based violence.

2) There will be significant relationship between nature of the families of migrants and satisfaction with their life in urban areas.

\section{Research Methodology}

The researcher adopted Snowball sampling technique. Sampling size were drawn 72 respondents head of the household. Self-Administered Questionnaire was selected for Data Collection. Data was presented in simple frequency distribution tables and hypotheses were tested by applying chi- Square technique. The universe of the present study was the following three District of the Balochistan such as: District Hub Chowki, District Gwadar and District Turbat.

\section{Results}

Personal Profile

\begin{tabular}{|c|c|c|}
\hline Age Information & Frequency & Percentage \\
\hline Below 40 years & 48 & $67 \%$ \\
\hline 46 years to Above & 24 & $33 \%$ \\
\hline Total & 72 & $100 \%$ \\
\hline \multicolumn{3}{|l|}{ Qualification } \\
\hline Illiterate & 25 & $35 \%$ \\
\hline Literate & 31 & $43 \%$ \\
\hline Other & 16 & $22 \%$ \\
\hline Total & 72 & $100 \%$ \\
\hline $\begin{array}{l}\text { Occupation } \\
\text { Unemployment }\end{array}$ & 25 & $35 \%$ \\
\hline Government Servant & 12 & $16 \%$ \\
\hline Other & 35 & $49 \%$ \\
\hline Total & 72 & $100 \%$ \\
\hline $\begin{array}{l}\text { Monthly Income } \\
\text { Below } 20,000\end{array}$ & 36 & $50 \%$ \\
\hline 21,000 to 30,000 & 21 & $29 \%$ \\
\hline $31,000 \&$ Above & 15 & $21 \%$ \\
\hline Total & 72 & $100 \%$ \\
\hline
\end{tabular}


The above table reflects basic personal information of the respondents according $67 \%$ of the respondents were below 40 years but mostly (43\%) were illiterate. As far as their occupation is concern $44 \%$ of respondents were in other's category which included skilled labor and small businesswhile, $50 \%$ of them earn below Rs. 20,000.

Push \& Pull Factors

\begin{tabular}{|c|c|c|}
\hline Hospital Facilities & Frequency & Percentage \\
\hline Yes & 24 & $34 \%$ \\
\hline No & 48 & $66 \%$ \\
\hline Total & 72 & $100 \%$ \\
\hline \multicolumn{3}{|c|}{ Education Opportunity } \\
\hline Yes & 22 & $31 \%$ \\
\hline No & 50 & $69 \%$ \\
\hline Total & 72 & $100 \%$ \\
\hline \multicolumn{3}{|l|}{ Insurgency Issues } \\
\hline Yes & 29 & $40 \%$ \\
\hline No & 43 & $60 \%$ \\
\hline Total & 72 & $100 \%$ \\
\hline \multicolumn{3}{|c|}{ Effect of Government Peace Operation } \\
\hline Yes & 61 & $85 \%$ \\
\hline No & 11 & $15 \%$ \\
\hline Total & 72 & $100 \%$ \\
\hline \multicolumn{3}{|c|}{ Family Directly Threatened } \\
\hline Yes & 7 & $10 \%$ \\
\hline No & 65 & $90 \%$ \\
\hline Total & 72 & $100 \%$ \\
\hline \multicolumn{3}{|c|}{ Unemployment Issue } \\
\hline Yes & 49 & $68 \%$ \\
\hline No & 23 & $32 \%$ \\
\hline Total & 72 & $100 \%$ \\
\hline
\end{tabular}

The above table indicates that $66 \%$ of the respondents don't have hospital facilities and $69 \%$ don't have educational opportunities in their hometown $60 \%$ of respondents claimed that they are scared of answering where as $85 \%$ of them agreed that they got effected due to government peace process but in this situation they point out that their families were not directly threatened. Lastly $68 \%$ of respondents were suffered by unemployment issue in their mother town. 
Psychological \& Health Conditions

\begin{tabular}{|c|c|c|}
\hline Seasonal Disease Found & Frequency & Percentage \\
\hline Skin Disease & 17 & $24 \%$ \\
\hline TB & 12 & $16 \%$ \\
\hline Malaria & 20 & $28 \%$ \\
\hline Heatstroke & 23 & $32 \%$ \\
\hline Total & 72 & $100 \%$ \\
\hline \multicolumn{3}{|c|}{ Professional Midwives Available } \\
\hline Available & 19 & $26 \%$ \\
\hline Not Available & 22 & $31 \%$ \\
\hline To some Extend & 31 & $43 \%$ \\
\hline Total & 72 & $100 \%$ \\
\hline \multicolumn{3}{|l|}{ Gender Base Violence } \\
\hline Yes & 18 & $25 \%$ \\
\hline No & 42 & $59 \%$ \\
\hline Don't know & 12 & $16 \%$ \\
\hline Total & 72 & $100 \%$ \\
\hline \multicolumn{3}{|l|}{ Mental Illness } \\
\hline Yes & 38 & $53 \%$ \\
\hline No & 34 & $47 \%$ \\
\hline Total & 72 & $100 \%$ \\
\hline \multicolumn{3}{|l|}{ Stress } \\
\hline Yes & 54 & $75 \%$ \\
\hline No & 11 & $16 \%$ \\
\hline Don't know & 7 & $9 \%$ \\
\hline Total & 72 & $100 \%$ \\
\hline
\end{tabular}

The above table shows that among seasonal diseases most of respondents (32\%) got heatstroke at present $43 \%$ of them have professional midwives availability to some extend, $59 \%$ of respondents don't have gender based violence issue. Mostly respondents (53\%) indicated prevalence of mental illnesses whereas, $54 \%$ of them are suffering from stress. 
Views and Experiences

\begin{tabular}{|l|c|c|}
\hline $\begin{array}{l}\text { Mentally Satisfaction with } \\
\text { Present Living }\end{array}$ & Frequency & Percentage \\
\hline Yes & 27 & $38 \%$ \\
\hline No & 12 & $16 \%$ \\
\hline To some Extend & 33 & $46 \%$ \\
\hline Total & $\mathbf{7 2}$ \\
\hline Suggest other Hometown Residents to migrate \\
\hline Yes & 56 \\
\hline No & 16 & $78 \%$ \\
\hline Total & $\mathbf{7 2}$ \\
\hline Justice is more Accessible & 18 & $22 \%$ \\
\hline Yes & 21 & $\mathbf{1 0 0 \%}$ \\
\hline No & 33 & $25 \%$ \\
\hline To some Extend & $\mathbf{7 2}$ \\
\hline Total & $29 \%$ \\
\hline Urban Community Better & 34 & $46 \%$ \\
\hline Yes & 11 & $\mathbf{1 0 0 \%}$ \\
\hline No & 27 & $47 \%$ \\
\hline To some Extend & $\mathbf{7 2}$ \\
\hline Total & $15 \%$ \\
\hline Willing to go Back & 19 & $38 \%$ \\
\hline Yes & 13 & $\mathbf{1 0 0 \%}$ \\
\hline No & 40 & $26 \%$ \\
\hline Don't Know & $\mathbf{7 2}$ \\
\hline Total & $\mathbf{1 0 0 \%}$ \\
\hline
\end{tabular}

The above table shows that $46 \%$ of the respondents are to some extend satisfied their living at present $78 \%$ of the respondents were agree to suggest other hometown residents to migrate. It was find out that $46 \%$ of respondents were to some extend agreed the justice is more accessible in urban area $47 \%$ of the respondents claimed that the urban community is better than the rural areas. Whereas $56 \%$ of the respondents don't have any idea either they have to go back to their hometown or wise versa.

\section{Hypothesis No.1}

H: There will be significant relationship between educational level and migration caused due to gender based violence. 
Ho: There will be no relationship between educational level and migration due to gender based violence.

\section{Contingency Table}

Educational level and migration caused due to gender based violence

\begin{tabular}{|l|c|c|c|c|}
\hline \multirow{2}{*}{$\begin{array}{l}\text { Migration due to Gender } \\
\text { based violence }\end{array}$} & \multicolumn{3}{|c|}{ Educational level } & \multirow{2}{*}{ Total } \\
\cline { 2 - 4 } & Literate & Illiterate & Other & \\
\hline Yes & $11(7.75)$ & $5(6.25)$ & $2(4.0)$ & $\mathbf{1 8}$ \\
\hline No & $14(18.1)$ & $18(14.6)$ & $10(9.33)$ & $\mathbf{4 2}$ \\
\hline Don't know & $6(5.17)$ & $2(4.17)$ & $4(2.67)$ & $\mathbf{1 2}$ \\
\hline Total & $\mathbf{3 1}$ & $\mathbf{2 5}$ & $\mathbf{1 6}$ & $\mathbf{7 2}$ \\
\hline
\end{tabular}

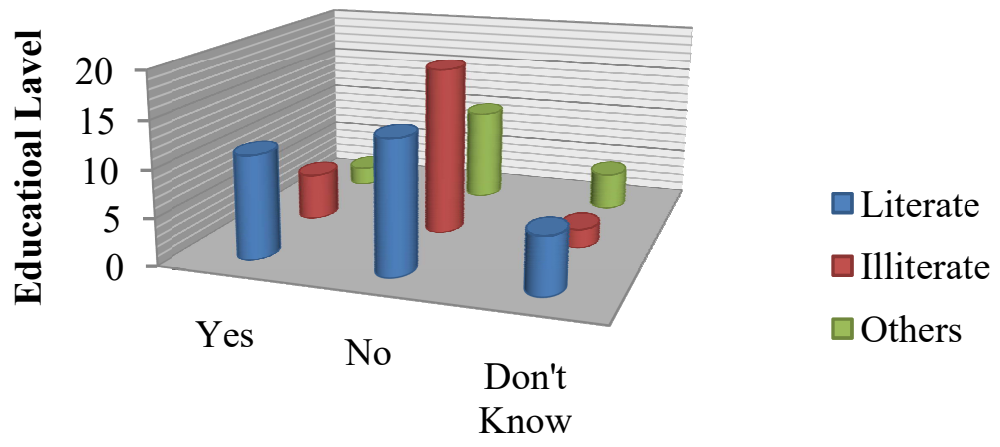

Migration due to Gender based violence

\section{Interpretation}

$\mathrm{X}^{2}=6.31$

$\mathrm{df}=4$

Table value at $4 \mathrm{df}$ at 0.05 level of significance $=9.488$

As the calculated value of chi-square is lesser than the table value of chi-square, it means that null hypothesis is accepted. So, there is no relationship between the migration due to gender based violence and the level of education among the respondents.

\section{Hypothesis No. 2}

H: There will be significant relationship between nature of the families of migrants and satisfaction with their life in urban areas.

Ho: There will be no relationship between nature of the families of migrants and satisfaction with their life in urban areas. 


\section{Contingency Table}

Nature of the families of migrants and satisfaction with their life in urban areas

\begin{tabular}{|l|c|c|c|c|}
\hline \multirow{2}{*}{ Nature of Family } & \multicolumn{2}{|c|}{ Satisfaction with their life in urban areas } & \multirow{2}{*}{ Total } \\
\cline { 2 - 4 } & Yes & No & To some extent & \\
\hline Nuclear Family & $14(12.0)$ & $6(5.33)$ & $12(14.7)$ & $\mathbf{3 2}$ \\
\hline Joint Family & $13(15.0)$ & $6(6.67)$ & $21(18.3)$ & $\mathbf{4 0}$ \\
\hline Total & $\mathbf{2 7}$ & $\mathbf{1 2}$ & $\mathbf{3 3}$ & $\mathbf{7 2}$ \\
\hline
\end{tabular}

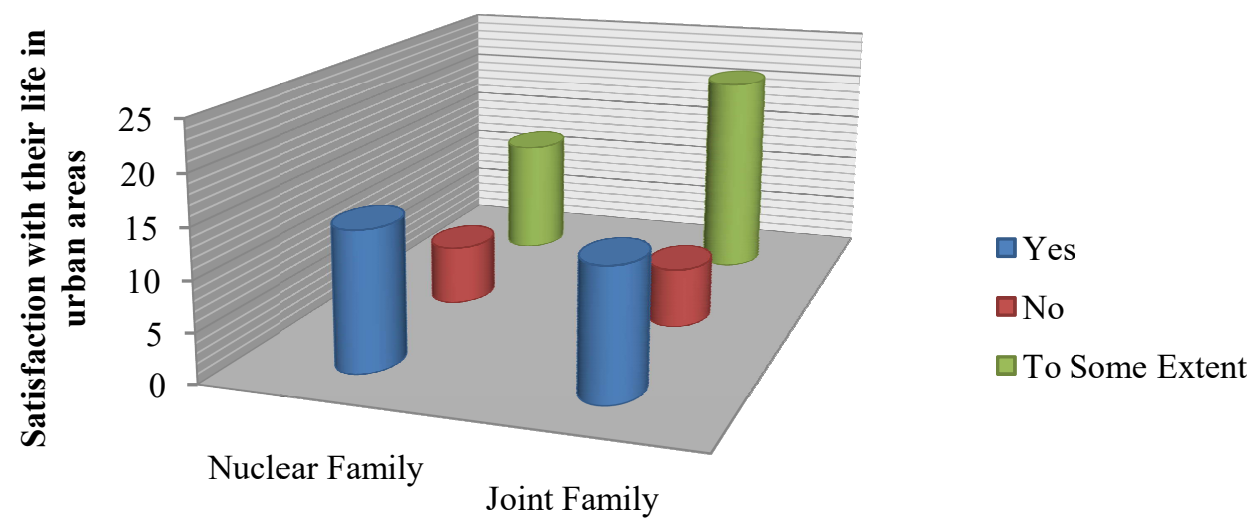

Nature of Family

\section{Interpretation}

$\mathrm{X}^{2}=1.62$

$\mathrm{df}=2$

Table value at $2 \mathrm{df}$ at 0.05 level of significance $=5.991$

As the calculated value of chi-square is lesser than the table value of chi-square, It means that null hypothesis is accepted. So, there is no significant relationship between nature of the families of migrants and satisfaction with their life in urban areas.

\section{Conclusions}

Given this notion, inter-provincial migration, the consequent acquisition of jobs by migrants and, most importantly, the ability of migrants to vote in provincial elections are often seen as attempts to affect the ethnic demography of an area. In fact, these appreciations are the result of the laissez-faire policy of the government regarding migration. Although, the good impacts of migration should be embraced fully, but there should be ensure that it must not contain violence.

Those who were connected through a chain of network were more eager to opt for migration keeping in light enhanced wage factor. It observed that the gender based violence was not the actual reason of migration. During data collection 
researcher observed that due to the limited basic facilities as well as insurgence issue became the alarming point for the migrants to move from their hometown.

The results indicates that occupation of $49 \%$ respondents were in the range of other which included skilled labor and small scale businessmen and $50 \%$ of the respondents' monthly income were below Rs.20,000. It was recognized that $66 \%$ of the respondents don't have hospital facilities in their hometown whereas $69 \%$ of the respondents were not availing education facilities. However, the data indicate that $60 \%$ of the respondents were not faced insurgency issue but mostly $(85 \%)$ respondents were affected by government peace operations. While $78 \%$ of the respondents were agree to suggest other hometown residents to migrate.

\section{Recommendations}

- The rapid trend to migrate from rural to urban areas shows mala fide intention of the government to develop cities and its lack of policies to develop rural areas.

- It will provide meaningful future urban planning in the country as migration has vast socio-economic impact upon habitants of the country.

- There are no restrictions with regard to the mobility of people they are free to move within the geographical boundaries of Pakistan.

- Secondly the government must insure that there is infrastructure development in the rural areas to improve the life style of population.

- By calculating the effects of rural-urban migration in the given study it is believed that the findings of this study help the government, NGOs, policy makers to start developing program to prevent rural-urban migration.

- Ultimately human capital development and skill acquisition centers should be setup in various parts of the areas to impart necessary training for the rural people. Besides providing them with employment and helping to stem the tide of rural-urban shift.

\section{Bibliography}

Ahmed, Noman. (2013,August 25). Growing Urbanisation Shifting Sands. Dawn, Karachi. Available on https://www.dawn.com/news/1038256

Akbar, S. M. (2014, June 10). The Basic Challenges that People in the Region. The New York Times.

Al, Et, Massey. (1993). Theories on Migration. Article. Vol.19:3, pp. 431-466. Available on https://www.jstor.org/stable/2938462

Arif, G. M. (2005). Internal Migration and Household Well-being: Myth or Reality. In Hisaya Oda (ed.) Internal Labour Migration in Pakistan. Institute of Developing Economies, Japan External Trade Organisation, Chiba, Japan. 
Baloch, A. (2014, March 28). From Zardaris to Makranis, How the Baloch Come to Sindh. Published by the Express Tribune. Available on https://tribune.com.pk/story/688234/from-zardaris-to-makranis-how-thebaloch-came-to-sindh/

Boswell, C. (2008). Combining Economics and Sociology in Migration Theory. Journal of Ethnicand Migration Studies, vol.34:4, pp.549-566.

Boyle, P., Halfacree, K. \& Vaughan, R. (1998). Exploring Contemporary Migration. New York: Pearson Education.

Chandio, R. M. (2014, December 30). Urbanization in Pakistan is only Shifting Poverty from Rural to Urban Centres. Report Express Newspaper, Karachi.

Chandio, M. (2016, March 20). Trans provincial migration. Published in Dawn Newspaper. Karachi.Available on https://www.dawn.com/news/1246245

Cooke, Thomas J. (2011). It is not Just the Economy: Declining Migration and the Rise of Secular Rootedness. Population, Space and Place, vol.17:3, pp.193-203.

Deshingkar, P. \& Grimm, S. (2004). Voluntary Internal Migration: An Accumulation AndExclusion, Working Paper No 220. Overseas Development Institute, London.

Dawn. (2008, September 01). The rising Rural \& Urban Migration. Article in Dawn Newspaper. Karachi. Available on https://www.dawn.com/news/319103

De, Haas, Hein. (2010). Migration and Development: A Theoretical Perspective. International Migration Reveiw, vol.44, pp.227-264.

De, H. A. \& Rogaly, B. (2002). Introduction: Migrant Workers and Their Role in Rural Change. Journal of Development Studies, vol.38:5, pp.1-14.

Denzin. (2005). Definition of Research Instrument. The SAGE Handbook of Qualitative Research(3rd Ed.). pp. 1-32.

Friesen, W. (1986). Labour Mobility and Economic Transformation in Solomon Islands: Lusim Choiseul bae kam baek moa? Auckland: Ph.D. Thesis, University of Auckland. Available on https://researchspace.auckland.ac. nz/docs/uoa-docs/rights.htm

Gazdar, H. (2003). A Review of Migration Issues in Pakistan. Collective for Social Science Research, Karachi, Pakistan. http://www.researchcollective.org/ Documents/A_Review_of_Migration_Issues_in_Pakistan.pdf 
Ghosh, B. (1992). Migration, Trade and International Economic Cooperation. Do the Interlinkageswork? In: International Migration, vol.30:3/4, pp.377-398.

Guardian Professional. (2013, December 18). We Urgently Need More Data on Internal Migration. The Guardian. Available on https://www.theguardian.com/global-development-professionalsnetwork/2013/dec/18/internal-migration-international-migrants-day

Hasan, A. (2011, October 27 ). Away from Home. Published in Dawn Newspaper. Karachi. Available on https://www.dawn.com/news

Hasan S. (2014, March 27). Experts Look at Challenges, Prospects of Internal Migration, Urbanization. Dawn Newspaper, Karachi. Available on https://www.dawn.com/news/1095765/newspaper/newspaper/column

Haykal, M. H. (1976). The Life of Muhammad. USA: North American Trust Publication, p.97.

Iqbal, Anwar. (2015, February 27). Many Educated People - Including Balochs - are Leaving Balochistan because of Violence. How Will You Stop this? (DR Malik Latest Interview). Available on https://www.dawn.com/news/1166129

Javed, B. (1973). The Population Census of 1951 Provided the Basis of Quantitative Work on the Subject. Migration, Urbanization and Politics in Pakistan. The Pakistan Development Review, vol.12:3, pp.293-310.

Peker, K. (2004). The Causes and Results of Internal Migration from Rural Areas: Case of Eastern Anatolia. Turkish Journal of Agriculture and Forestry, vol.20, pp.183-190.

Kainth, G.S. (2009). Push and Pull Factors of Migration: A Case of Brick Kiln Industry of Punjah State. Asia-Pacific Journal of Social Sciences, vol.1, pp.82-116.

Karim, M. \& Abu, Nasar. (2003). Migration Patterns and Differentials in Pakistan: Based on the Analysis of 1998 Census Data, in Population of Pakistan: An Analysis of 1998. Population and Housing Census, pp.213-226.

Kok, P., Gelderblom, D., Oucho, J. \& van Zyl, J. (eds), (2006). Introduction. In Kok, P., Gelderblom, D., Oucho, J. \& van Zyl, J. Migration in South and Southern Africa: Dynamics and Determinants. Cape Town. Available on https://www.researchgate.net/publication/235907806

Lee, E. S. (1966). A Theory of Migration. Demography, vol.3:1, pp.47-57. 
Lincoln \& Guba's. (1985). Instuments, Validity, Reliability. Qualitative Market Research, vol.3:3, pp.118-126.

Mangalam, J. J. \& Schwarzweller, H. K. (1970). Some Theoretical Guidelines Towards Sociology of Migration. International Migration Review, vol.4:2, pp.5-21.

Memon, R. (2005). Determinants and Trends of Internal Migration in Pakistan. pp.139. Available on http://www.unescogym.org/wp-content/uploads/2017/08

Mahreen, M., Tareena, M. \& Farah, S. (2010). Internal Migration Patterns in Pakistan the Case for Fiscal Decentralization. The Pakistan Development Review, vol. 49:4, pp.593-607.

Ministry of Population Welfare. (2002). Population and Development Policies. The Pakistan Development Review, vol.6:2, pp.255-281.

Montgomery. (2008). Points Out that the Projection of Urban Population. Research and Reports Studies. United Nations.

NARA. (2017). National Aliens Registration Authority. Available on https://www.revolvy.com/page/National-Alien-Registration-Authority

Notezai, A. M. (2016, March 20). Tug of Nationalisms in Balochistan. Published in Dawn News Paper. Karachi. Available on https://epaper.dawn.com/

Neuman, W. L. (2000). Social Research Methods Qualitative and Quantitative Approaches (4rt ed.). USA: Allyn \& Bacon, pp. 122-124.

OECD (2009) International Migration Outlook, SOPEMI. pp.1-224. Available on https://www.oecd.org/els/mig/internationalmigrationoutlook2009.htm

PDMA. (2012). Provincial Disasters Management Authority of Balochistan Profile. Available on http://www.pdma.gob.pk/

Portes, A. \& Böröcz, J. (1989). Contemporary Immigration: Theoretical Perspectives on its Determinants and Modes of Incorporation. In: International Migration Review, vol.23:3, pp.606-630.

Potts, D. \& Mutambirwa, C. (1997). The Government Must not Dictate: RuralUrban Migrants Perceptions of Zimbabwe's Land Resettlement programme, Review of African Political Economy, vol.24:74, pp.549-566. 
Qaisrani, Ayesha. (2016, October 01). Planning for Internal Migration. Published in Pakistan Today. Available on https://www.pakistantoday.com.pk/2016/ 10/01/planning-for-internal-migration/

Ravi, S. (2017). Internal and International Migration in South Asia: Drivers, Interlinkage and Policy Issues. Jawaharlal Nehru University (JNU). Available on https://www.researchgate.net/publication/317834986

Scutt, R.K, (2004). Investigating the Social World (4rt ed.). London: Sage Publication. pp.129-130.

Sjaastad, L. A. (1962). The Costs and Returns of Human Migration. The Journal of Political Economy, vol.70:5, pp.80-93.

Solimano, A. (2002). Globalizing Talent and Human Capital: Implications for Developing Countries. ABCDE Conference Europe, Oslo. pp-33-44. Available on https://www.rrojasdatabank.info/lcl1773i.pdf

Tiebout. (1956). Internal Migration Patterns in Pakistan. The Pakistan Development Review. Pp.11-16.

Montgomery, M. \& Engebrestsen, S. (2013). Internal-Migration-InternationalMigrants-Day.United Nation, pp.23-29.

United Nation. (2009). Population Distribution, Urbanization, Internal Migration and Development: An International Perspective. United Nations Department of Economic and Social Affairs Population Division. Pp.1-12.

UNOCHA. (2010). Human Security at the United Nations Otflce för the Coordination of Humanitarian Affairs. New York.Oxford University Press. Chapter 2, pp.22-40.

Nisar Ahmed is Ph.D Scholar in the Department of Social Work, University of Karachi, Karachi, Pakistan.

Dr. Sumera Ishrat is an Assistant Professor in the Department of Social Work, University of Karachi, Karachi, Pakistan. 